\title{
Vertebrate track bed stratigraphy of the Röt and basal Lower Muschelkalk (Anisian) of Winterswijk (East Netherlands)
}

\author{
C. Diedrich ${ }^{1}$ \\ 1 Steinfurter Str. 128, D-48149 Münster, Germany; email: cdiedri@gmx.net, website: \\ http://www.geocities.com/Cape Canaveral/Lab/1654.
}

Received: 28 June 2000; Accepted in revised form 18 March 2001

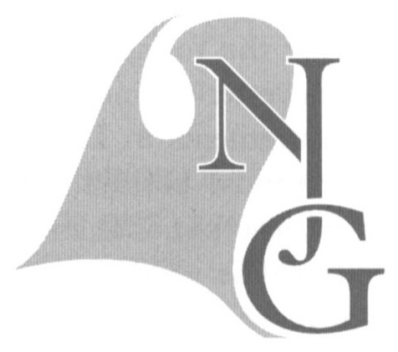

\begin{abstract}
The $35.5 \mathrm{~m}$ thick Anisian section of the Winterswijkse Steen- en Kalkgroeve (Eastern Netherlands) comprises the Upper Röt (Upper Röt Claystone Member) to the basal Lower Muschelkalk (Oolith Member). In the section 15 terrestrial or marine influenced parasequences are recognized. A fourth order sequence shows the increasing marine influence. New marker beds, ten vertebrate track beds, three bone beds and cephalopod remains have been documented. This enabled correlation to other sections in NW Germany. The tracks found in the Winterswijkse Steen- en Kalkgroeve at the boundary Röt/Lower Muschelkalk are linked to the oldest known vertebrate skeleton remains of the Germanic Basin. It is the first time that the exact stratigraphic position of these vertebrate remains has been established. In the terrestrial influenced section of the Winterswijkse Steen- en Kalkgroeve, the well preserved vertebrate track ways and vertebrate fauna will be of international importance and will provide new data of the Triassic carbonate tidal flat megatracksite concept and reptiles living in this environment.
\end{abstract}

Key words: Anisian, Germanic Basin, lithostratigraphy, sequence stratigraphy, biostratigraphy, track bed stratigraphy, and megatrack sites.

\section{Introduction}

The first stratigraphic descriptions of the Winterswijkse Steen- en Kalkgroeve section (Gauss-Krüger coordinates: R 2252,60 H 5758,60) (Fig. 1) can be found in Harsveldt (1963, 1973) and Oosterink (1986).

In a palynological study, Visscher \& Commissaris (1968) demonstrated the presence of Upper Bunter and Lower Muschelkalk assemblages in rocks of the older quarries. De Boorder et al. (1985) described iron, lead and zinc mineralizations in the rocks from that area and Oosterink (1986) identified some vertebrate track beds and one bone bed in his section. Recently, the stratigraphy of this section has been updated (Diedrich \& Oosterink, 2000) using the international or German subdivision of the Middle Triassic
Lower Muschelkalk (e.g. Bachmann 1998) of the Germanic Basin into Members.

In 1973 the section was exposed down to the Dolomite III ("Dolomite limestone VT' after Harsveldt, 1973, Fig. 2). Harsveldt (1973) recognized six dolomitic horizons with coelestin and calcite concretions (Dolomitic limestone I-VI, Fig. 2), which he described as marker beds. The classification of the dolomitic beds of Harsveldt, 1973 is top-down, whereas the new numbering in the new section is in the normal stratigraphical order (Fig. 2). Harsveldt (1973) distinguished five lithological units: the Upper Bunter, the Lower Wellenkalk, the Upper Wellenkalk, the Clayey Marl and the Calcareous Marl (Fig. 2).

Vertebrate track beds found in the Osnabrücker Bergland, Teutoburger Wald and North Hessia (all located in Northern Germany) have provided essential 


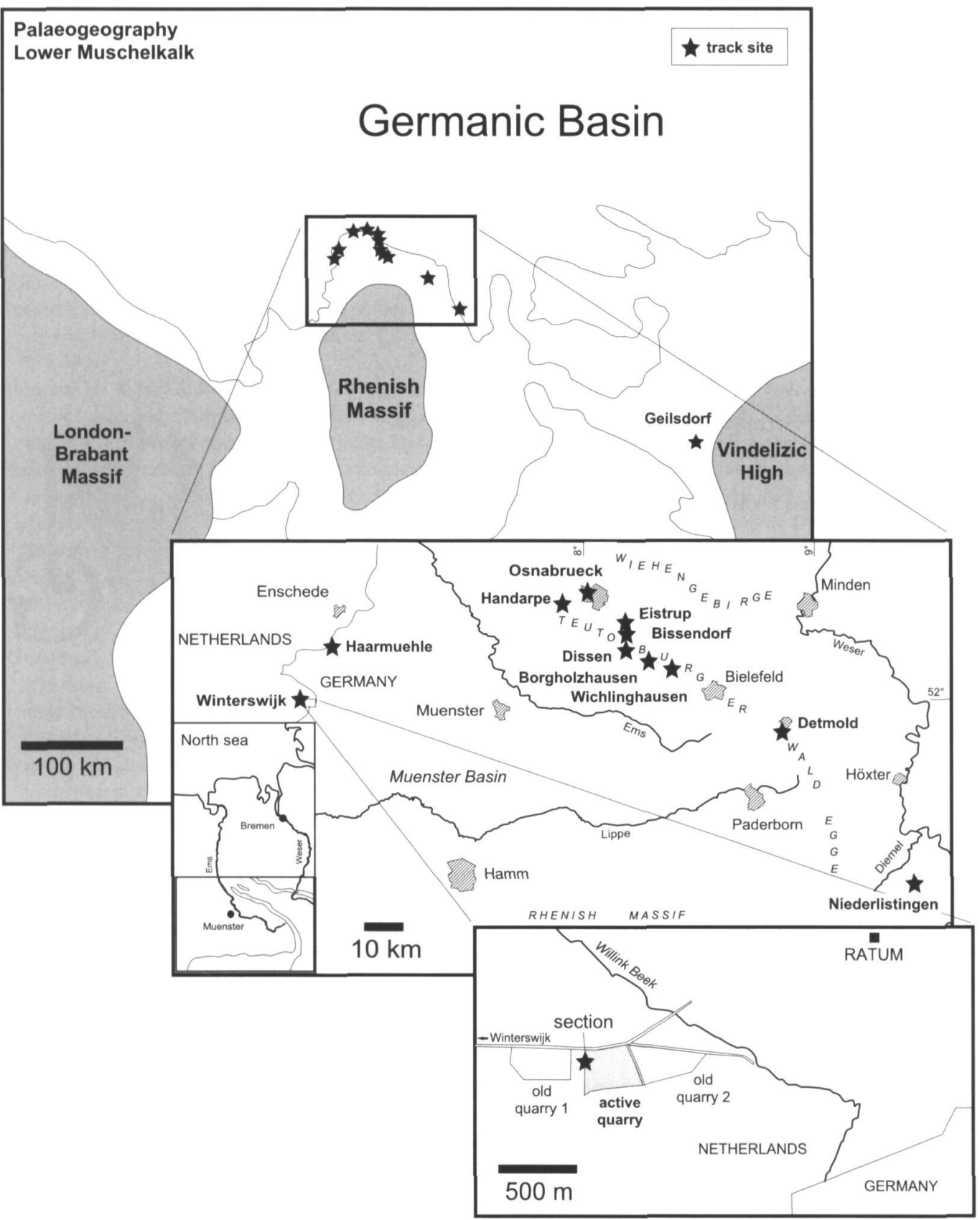

Fig. 1. Location of the studied section in the new quarry of the Winterswijkse Steen- en Kalkgroeve near Winterswijk and palaeogeography showing current vertebrate track sites of the Lower to Middle Muschelkalk (Middle Triassic) of North West Germany.

data for correlating sections within the western Germanic Basin (Diedrich 2000b, 2001a). They have furthermore been helpful in subdividing the Muschelkalk of Winterswijk by means of lithology, track beds, sedimentary cycles and biostratigraphy of macrofossils (e.g. cephalopods). A new project to correlate the Lower Muschelkalk, applying various stratigraphic disciplines in the entire Germanic Basin, is still in progress. Recently subdivisions have been introduced based on track beds (Diedrich, 2000b), tsunamites or seismites (Knaust, 1998b) and palynomorphs (Götz \& Feist-Burkhardt, 1998). Track beds were formed in an intertidal terrestrial influenced facies, whereas seismites represent marine subtidal conditions.

The high-resolution stratigraphy of track beds in many Triassic sections from different locations will yield further information about the megatracksite concept. These megatracksites will give information on the distribution of carbonate tidal flats in time and space in the future.

Finally the new stratigraphic subdivision of the Winterswijkse Steen- en Kalkgroeve section is important for the exact position of the skeleton remains found the last years. In the basal bone bed the most ancient skeletons of the Germanic Triassic reptiles were found. These fossils will yield very important 


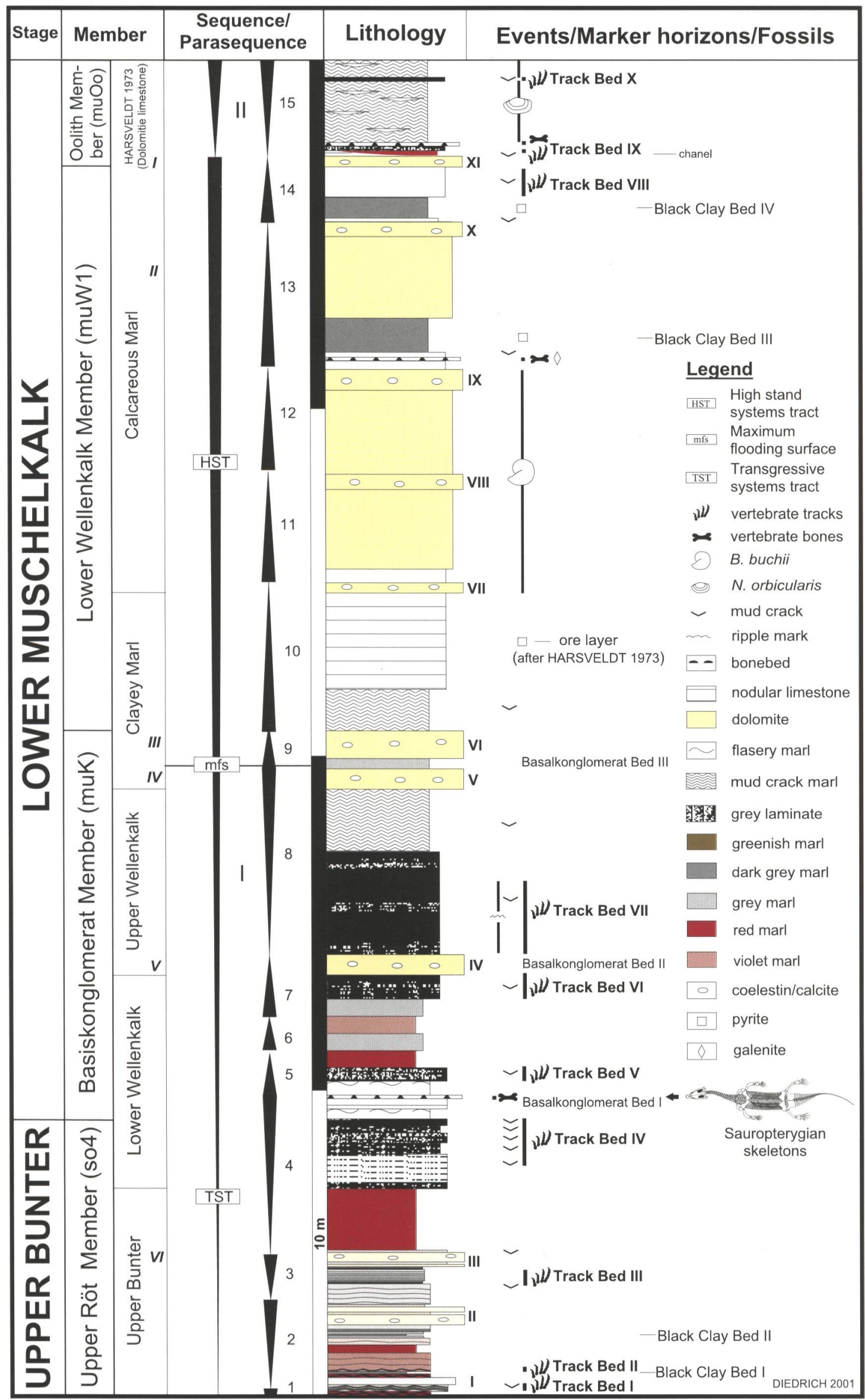

Fig. 2. Complete section of the Lower to basal Middle Muschelkalk in the new quarry of the Winterswijkse Steen- en Kalkgroeve. 
systematic and phylogenetic information in due time. But the most important conclusion is that there is a possible link between tracks and the track makers at this renowned fossil site.

A website www.geocities.com/ CapeCanaveral/ Lab/ 1654/vertebratetracks.html to the "Triassic megatracksites in carbonate tidal flats of the Germanic Basin" is still under construction, new sections, track types and track sites will be added in due time.

\section{Lithostratigraphy}

In the Netherlands the Röt Formation is divided into four Members, the Main Röt Evaporite, the Intermediate Röt Claystone, the Upper Röt Evaporite and Upper Röt Claystone Member (cf. Van Adrichem Boogaert \& Kouwe, 1994; Geluk \& Röhling, 1998). In Germany the subdivision differs slightly. The Salinarröt Formation consists of the Members Unteres Rötsalinar, Rötsalinar-Zwischenschichten and Oberes Rötsalinar. The Pelitröt Formation is divided into the Rotbraune Serie and the Grauviolette Serie.

The Lower Muschelkalk Formation (Jena Formation after Bachmann, 1998; or Lower Muschelkalk Member after Van Adrichem Boogaert \& Kouwe, 1994) in the marine facies of the Germanic Basin consists of $90-150 \mathrm{~m}$ carbonates. It is subdivided into the Basalkonglomerat Member (muK), Lower Wellenkalk Member (muW1), Oolith Member (muOo), Middle Wellenkalk Member $\left(\mathrm{muW}^{2}\right)$, Terebratula Member (muT), Upper Wellenkalk Member $\left(\mathrm{muW}^{3}\right)$ and Schaumkalk Member (muS) (see e. g. Schulz, 1972, Langer, 1989, Rosenfeld \& Thiele, 1992, and Knaust 1998a). This subdivision has been established in the marine influenced basin centre. In a condensed marginal facies, the lithostratigraphic subdivision differs due to the presence of siliciclastic littoral deposits. In the Netherlands, the Lower Muschelkalk has not been further subdivided but in the Winterswijkse Steen- en Kalkgroeve we could recognize the German subdivison. Hence, that classification has been applied here.

In the Winterswijkse Steen- en Kalkgroeve section the Upper Röt Claystone Member (or Pelitröt Member) and the basal part of the Lower Muschelkalk Formation (Basalkonglomerat to Oolith Members) are present with a total thickness of $35.5 \mathrm{~m}$ and can be described as follows:

\section{Röt Formation}

The total thickness of the Röt Formation, can be obtained from the published logs of Winterswijk-1 (NITG-TNO, 1998). Only $8.2 \mathrm{~m}$ of the top of the
Upper Röt Claystone Member (so4 or Pelitröt in Northwest Germany) is partly exposed in the Winterswijkse Steen- en Kalkgroeve.

\section{Upper Röt Claystone Member}

This member comprises three dolomitic Beds I-III (Fig. 2) and grey, dark grey, red-violet and greenish marls (Van Adrichem Boogaert \& Kouwe, 1994, NITG-TNO, 1998). Coelestin and calcite concretions are present in the yellowish $30-40 \mathrm{~cm}$ thick dolomitic horizons (Harsveldt, 1973, Oosterink, 1986).

Mud-cracked laminates overlay the dolomites. Clear visible are the dark coloured Black Clay Bed I $(10 \mathrm{~cm})$ and dark grey Black Clay Bed II $(20 \mathrm{~cm})$. Both contain pyrite. Red marls $(1.8 \mathrm{~m})$ and grey mud-cracked laminates $(1.85 \mathrm{~m})$ form the top of this member.

The first vertebrate track beds of Rhynchosauroides peabodyi (Faber) and Procolophonichnium haarmuehlensis (Holst, Smith \& Veenstra) were found below Dolomite I (Track Bed I) and a second bed above Dolomite I in laminate beds (Track Bed II). A third track bed appears $2.6 \mathrm{~m}$ above the Dolomite $\mathrm{I}$ in greygreenish, mud-cracked laminates (Track Bed III).

\section{Lower Muschelkalk Formation}

In the Netherlands, the complete Lower Muschelkalk Formation (or Member cf. Van Adrichem Boogaert \& Kouwe, 1994) consists of a 100-121 m thick succession of yellowish dolomites, greyish limestones, grey marls and dark grey claystones (Van Adrichem Boogaert \& Kouwe, 1994; Geluk, 1998, NITG-TNO, 1998). In the Winterswijkse Steen- en Kalkgroeve this unit has a thickness of $31.3 \mathrm{~m}$ and consists of the Basalkonglomerat Member, the Lower Wellenkalk Member and the Oolith Member (Fig. 2).

\section{Basalconglomerate Member}

The base of the Basalconglomerate Member is formed by the Lower Basalconglomerate Bed. This $4.3 \mathrm{~m}$ thick unit consists of grey bioturbated marl, and contains a very important bone bed. Between the Lower and Upper Basalkonglomerat Bed laminates, red-violet and grey marls are present. Ripple and oscillation sediment surface marks are significant in some horizons. In the upper part (Track Bed VI and VII), the mud-crack polygons are very small (diameter of 20 $\mathrm{cm}$ ) in contrast to Track Bed IV and V. Here, large polygons of $50 \mathrm{~cm}$ in diameter are typical. The Upper Basalconglomerate Bed consists of two dolomite beds, the Dolomite V $(60 \mathrm{~cm})$ and VI $(80 \mathrm{~cm})$ ("Dolomitic limestone $I V$ and $V$ " after Harsveldt, 1973, Fig. 2), in which $30 \mathrm{~cm}$ grey marl is intercalated. 
There are many bone remains of a very diverse sauropterygian and fish fauna in the Basalconglomerat Bed I (cf. Oosterink, 1986). Reptiles are present, including Tanystropheus sp., Nothosaurus sp., and "Anarosaurus sp." (Oosterink, 1986). Fishes can be identified by teeth of Acrodus sp., Palaeobates sp., and Colobodus sp., the scutes of Coelacanthus sp., and $G y$ rolepis sp., and the skeletons of Dollopterus sp., Pholidophorus sp., Saurichthys sp., and Eoseminotus sp. (Oosterink, 1986).

The laminates (Track Bed V and VI) mostly contain the track types $R$. peabodyi and $P$. haarmuehlensis. Some further rare ichnospecies Brachychirotherium paraparvum Demathieu \& Oosterink and Coelurosaurichnus ratumensis Demathieu \& Oosterink There are also scratch and tail marks (Demathieu \& Oosterink, 1983, and 1988) present and this interval contains a more diverse ichnofauna reaching up to the Track Bed VII. The described "ichnospecies" Sustenodactylus hollandicus Demathieu \& Oosterink, Phenacopus faberi Demathieu \& Oosterink, Phenacopus agilis Demathieu \& Oosterink and Capitosauroides sp. seem to be nothing else than different preservation types or tracks of juvenile reptiles producing the first four mentioned track types. A revision of the ichnofauna is still in preparation. Track Bed VII contains fewer vertebrate tracks of $R$. peabodyi and $P$. haarmuehlensis.

\section{Lower Wellenkalk Member}

The Lower Wellenkalk Member starts with $9.9 \mathrm{~m}$ Wellenkalk, platy limestones and the dolomitic beds VII and VIII that show more marine subtidal conditions. This member consists of yellowish dolomites and dark grey marls (Black Clay IX-XI). Furthermore, a nodular limestone with a bone bed is present. In the marly clays, pyrite is common. The Dolomites IX-XI are part of the Lower Wellenkalk Member. An- other track bed (VIII) consists of mud-cracked laminates underlying Dolomite XI.

$R$. peabodyi and $P$. haarmuehlensis were retrieved in the Track Bed VIII. In the dolomites different invertebrates like lamellibranchs, gastropods and the cephalopod Beneckaia buchi (Alberti) are present (cf. Oosterink, 1986).

\section{Oolith Member}

The boundary between the Lower Wellenkalk Member and the Oolith Member is marked by a bone bed and the abundant presence of Neoschizodus orbicularis (Bronn) at the top of the section. At the base a huge, about $30 \mathrm{~m}$ wide, channel filled with red mudcracked marls is exposed in the western part of the active quarry (Fig. 2).

In the grey marls many invertebrates (lamellibranchs, gastropods) are present. Between the marls lumachelle-filled channels and isolated vertebrate remains are typical. Here, the last two vertebrate track beds (Track Bed IX and X) containing $R$. peabodyi and $P$. haarmuehlensis are present in two $5-20 \mathrm{~cm}$ finely laminated, mud-cracked marls.

\section{Sequence stratigraphy}

A first sequence stratigraphic interpretation is presented following German Muschelkalk subdivisions (comp. Aigner \& Bachmann, 1991; Knaust, 1998a, b; Götz \& Feist-Burkhardt, 1999).

In the Winterswijk section 15 parasequences and two different parasequence types (a terrestrial and a marine influenced; Fig. 3) can be distinguished. A terrestrial influenced coarsening-upward parasequence (Fig. 3A) in the Winterswijk section starts with red marls. It is followed by grey marls changing into mud-cracked laminates with tracks and biotur- proximal terrestrial influenced

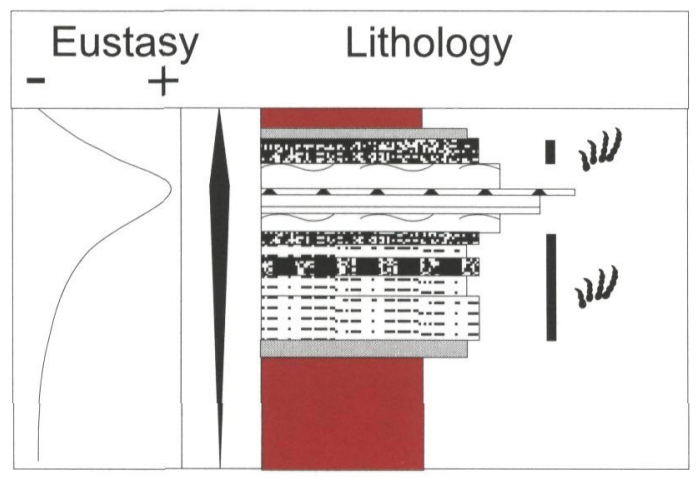

A distal marine influenced

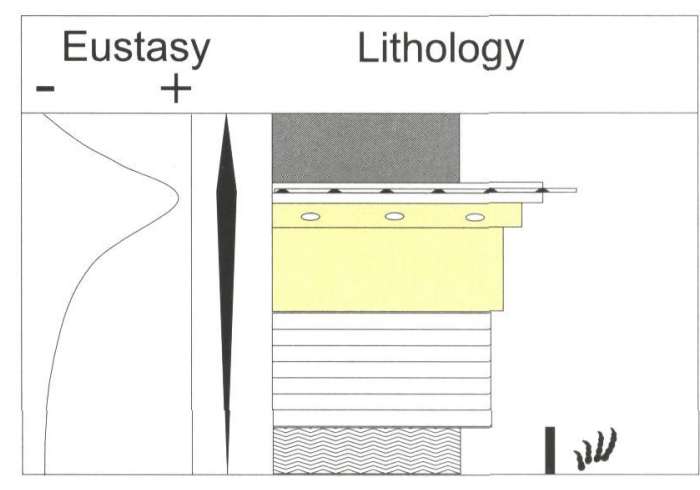

B

Fig. 3. Parasequence types in the section of Winterswijk. A. terrestrial influenced parasequence, B. marine influenced parasequence. 
bated grey marl. It finally ends in a bone bed. Red marls form the top of the fining-upward parasequence. Another marine influenced type of a coarsening-up parasequence (Fig. 3B) starts with dark grey pyritic marls. Mud-cracked laminates with ripple marks lay on top of it. The sediments change to dolomites, and are finally covered by zinc enriched bone beds (Fig. 3B). The bone bed is the base of a fining-upward parasequence.

A higher category sequence (fourth order) is present in the section (Fig. 2, sequence I). It ranges from the top of the Röt to the Oolith Member. At the base the terrestrial influenced parasequence shows the first marine influence with the periodically occurring of intertidal laminates. The high stand systems tract is represented by the shell-rich beds (Dolomite VII-IX) and the marine fauna, especially by the cephalopod B. buchi in the upper part.

\section{Biostratigraphy}

Cephalopods such as Beneckeia buchi (Alberti) are important fossils for biostratigraphic correlation of the Winterswijk section with the reference section in Northwest Germany (Fig. 4). However, these fossils are very rare in Winterswijk and they are only present between dolomite Bed VII and IX, due to the marginal marine depositional setting. Oosterink (1986) pictured one small cephalopd found in the upper dolomitic part of the Muschelkalk section and collected six specimens of B. buchi between Dolomite VII to IX $\left(=\mathrm{muW}^{1}\right)$.

The frequent occurrence of Neoschizodus orbicularis (Bronn) in the Oolith Member (Fig. 2), was originally thought to be typical for the Middle Muschelkalk (orbicularis Member). At present it is assumed that the presence of this lammelibranch is only controlled by facies (restrictive hyper saline conditions) and therefore is not useful for biostratigraphic correlations.

There are three bone beds present in Winterswijk (Fig. 2) containing isolated bones and skeletons. The first and most important is Bone bed I (Lower Basalkonglomerat Bed) in the Basalkonglomerat Member. Diverse reptile- and ichthyofaunas are described from the Winterswijk quarry (Demathieu \& Oosterink, 1983, 1988; Oosterink, 1986, 1988). There are still some unidentified sauropterygian skeletons present that are not yet described. A study of recent findings will be done in future. The bones of a second bone bed in the Lower Wellenkalk Member (muW1) have not yet been described. A third bone bed is situated at the base of the Oolith Member (Fig. 2) and its presence and contents have also not been communicated earlier.

\section{Discussion}

The terrestrial influenced section $(35,5 \mathrm{~m})$ as exposed in the Winterswijkse Steen- en Kalkgroeve (East Netherlands) comprises the uppermost Upper Röt to basal Lower Muschelkalk. This lithology differs from contemporaneous sections in the Osnabrücker Bergland (Langer, 1989), the Teutoburger Wald (Rosenfeld \& Thiele, 1992) and in Lower Saxony (Schulz, 1972). At those locations, a more marine section of 90-120 m carbonates is present (c.f. Fig. 4). In the Eastern Germanic Basin the Lower Muschelkalk attains thicknesses up to $150 \mathrm{~m}$ in the basin centre near Rüdersdorf (Zwenger, 1992).

There are some important marker beds in the Winterswijk section. According to Diedrich (2001c), a dark-coloured marker clay bed in the Upper Röt Claystone Member of Winterswijk can be correlated with a bed in the Balsalkonglomerat Member in a condensed section in Geilsdorf (South Thuringia, Southeast Germany). A channel deposit such as the one in the Oolith Member in Winterswijk was mentioned from a section at Wichlinghausen (Teutoburger Wald, North West Germany, c.f. Fig. 4), that eroded into the Graue Zwischenmittel (Oolith Member). In Wichlinghausen redviolet $50 \mathrm{~cm}$ thick laminated mud-cracked and track bearing marls appear as channel deposits (Diedrich, 1998b). Its lateral distribution amounts to several kilometres. The latest red marls of the Lower to Middle Muschelkalk intercalate into the orbicularis Member and are typical of the lowermost Middle Muschelkalk in the western Germanic Basin (Lotze, 1933).

A higher category of high frequency sequence (fourth order, Aigner \& Bachmann, 1991) is visible and correlates with the interpretation for the Germanic sections (cf. Knaust, 1998a). The transgressive systems tract starts at the top of the Upper Röt. The occurrence of red marls and track beds in the lower part of the section (so4) witness a terrestrial environment with a first marine influence in the lower part of the Winterswijk section. The intercalating mudcracked laminates are typical of the intertidal, marginal marine facies of the carbonate tidal flat. The rising marine influence in the Basalkonglomerat Member to Lower Wellenkalk Member is shown by the increase of dolomites and the occurrence of marine invertebrates of the subtidal realm such as lamellibranchs and the cephalopod B. buchi. The maximum flooding surface of the Lower Muschelkalk located in the Terebratula Member (cf. Knaust, 1998a) is not present in the Winterswijk section.

In marine deposits (e. g. in Borgholzhausen and Wichlinghausen) $B$. buch $i$ is frequently present in the Basalkonglomerat beds and in the Lower Wellenkalk 


\section{East Netherlands}

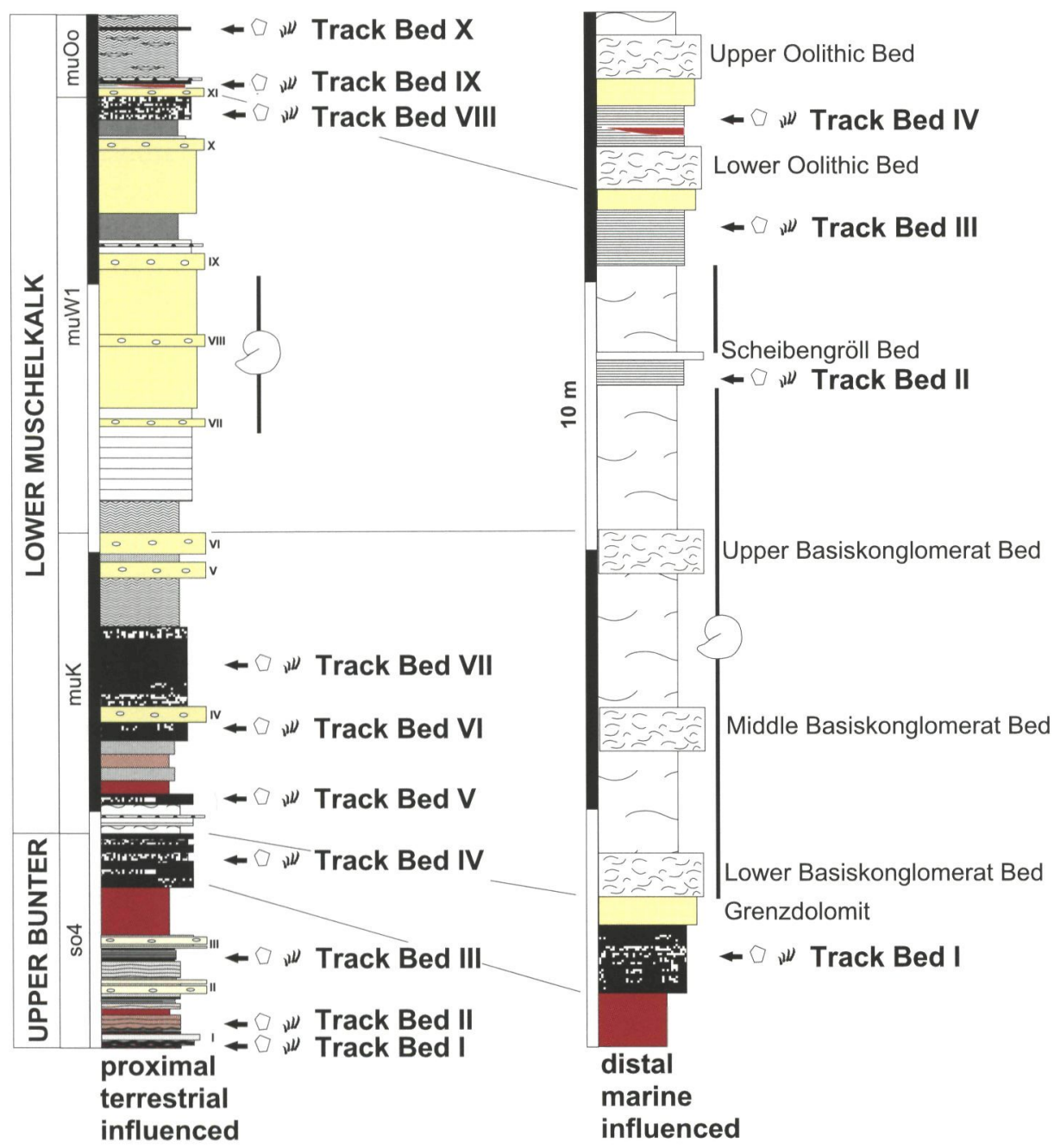

\section{Legend}

iil) vertebrate tracks

B. buchii

mud crack

bioclastic limestone

bioturbate marl

nodular limestone

dolomite

flasery marl

mud crack marl

I.7. grey laminate

greenish marl

dark grey marl

grey marl

red marl

violet marl

coelestin/calcite

Fig. 4. Correlation of the Winterswijk section of East Netherlands to a generalized section of the uppermost Upper Röt Claystone Member to the Oolith Member and occurrence of track beds and megatracksites.

Member, mostly concentrated in shell beds (Fig. 4).

Palynological research by means of pollen and spores, has also pointed to a terrestrial influence on the Winterswijk section (Visscher \& Commissaris, 1968). They also have disclosed an Upper Bunter (Röt) palynological assemblage, although the samples must have been taken from the upper part of the Muschelkalk section, but no clear stratigraphic data of the samples were given. According to their descriptions, the spores came from the dolomites in the Lower Wellenkalk Member (muW1). The assemblages show that the terrestrial conditions prevailed from the Röt to the Lower Wellenkalk Member.

Many vertebrate track beds contain much information on stratigraphy, palaeogeography and sedimentary facies. Especially tracks of $R$. peabodyi and $P$. haarmuehlensis are typical for the marginal carbonate tidal flat and sabkha surrounding of the old massifs like the Rhenish Massif or the Vindelizic Massif (Diedrich,
$2000 \mathrm{~b}, \mathrm{c})$. Various sedimentary structures in these beds such as mud cracks and ripple marks point to intertidal conditions (Schwarz, 1975). This was also inferred for the Winterswijk Muschelkalk (De Boorder et al., 1985) and many track sites in the Osnabrücker Bergland and Teutoburger Wald (Diedrich, 2000b). A new subdivision of the Winterswijk section is possible as a result of vertebrate track beds, which often form megatrack sites in Middle Triassic carbonate tidal flats (Diedrich, 1998b, 2000b). Vertebrate tracks are becoming more and more important for regional correlation and facies interpretation in the Lower Muschelkalk (Diedrich, 1997, 1998a, b, c, 1999, $2000 a, b, c)$, especially if other biostratigraphic information is lacking or scarce such as in Winterswijk. Here, vertebrate tracks are present in ten beds in the Upper Röt to the basal Lower Muschelkalk. The oldest known vertebrate tracks are in greenish mudcracked marls below and on top of Dolomite I. Below 
Dolomite III another mud - cracked track bed contains the same track types. One of the most important vertebrate track beds is the boundary between the Upper Röt Claystone Member (or Pelitröt, Upper Bunter) and Basalkonglomerat Member (Lower Muschelkalk). The top of the Upper Röt Claystone Member (Track Bed IV) seems to correlate with the "Grenzdolomit" of Germany (Fig. 4). Rhynchosauroides peabodyi (Faber) and Procolophonichnium haarmuehlensis (Holst, Smit \& Veenstra) ( $=P$. winterswijkense) were collected in this track bed at many localities in North Germany (unpublished data). This track bed contains dozens of track horizons and can be found over a distance of 400 kilometres in the entire Germanic Basin. The Grenzdolomite represents a megatracksite sensu Meyer (1993). Track Bed IV is isochronous to some unpublished track sites recently found in Northwest Germany. They will be discussed in a future paper on the megatracksite of the Grenzdolomite. The Track Beds I-IV belong to the Upper Claystone Röt Member (Fig. 2). Track beds V-X are situated in the basal Lower Muschelkalk. Three of these vertebrate track beds are in the Basalkonglomerat Member of Winterswijk (Track BedV to VII). Another track bed (Track Bed VIII) represents the top of the Lower Wellenkalk Member (muW1) and forms a megatracksite together with Borgholzhausen and Osnabrück (cf. Diedrich, 2000b, d). The youngest two track beds of Winterswijk are some $\mathrm{cm}$-thin layers in the Oolith Member (Track Bed IX and X, Fig. 2, 4). The vertebrate tracks in Borgholzhausen (Diedrich, 2001b), and also the sites Handarpe and Dissen (Osnabrücker Bergland, NW Germany, Diedrich, 1997, $2000 \mathrm{~b}$ ) are isochronous, forming a second megatracksite. The tracks at these localities occur between the Lower and Upper Oolith Bed. Of importance are tracks in the red-violet marls of the channel deposits found in Wichlinghausen (Diedrich, 1998b). At the moment there is no proof of tracks in the channel deposits of Winterswijk.

There are more track beds in the Upper Röt and basal Lower Muschelkalk in Winterswijk than in the Osnabrücker Bergland (Diedrich, 2000b). In Winterswijk seven track beds have been found between the Grenzdolomite and the Oolith Member while the well-studied area of the Osnabrücker Bergland comprises not more than four track beds. They are found in the interval reaching from the Grenzdolomite to the muW1B-top, the muW1C-top and the Graue Zwischenmittel and in between the Oolithic beds (Fig. 3, Diedrich, 2000b). The high number of track beds in Winterswijk is another proof of the terrestrial influenced, marginal marine facies.

In addition to isolated reptile bone remains, the
Basalkonglomerat Bed I and track bed IV contain articulated vertebrate skeletons. These are the oldest known skeletons in the Germanic Basin. It is the first time that the exact stratigraphic position of these vertebrate remains has been established. The Basalkonglomerat Bed I can be placed in the lowermost Lower Muschelkalk. This exact stratigraphic position will be very important for understanding the diversification of Triassic vertebrates. These vertebrates have probably created the vertebrate tracks. The most interesting find is an unidentified skeleton in the mud-cracked laminates of the track bed IV very near to an imprint of Rhynchosauroides peabodyi.

Finally, the well-preserved vertebrate track ways and vertebrate fauna of the Winterswijkse Steen- en Kalkgroeve will be of international importance and will provide new data on the Triassic carbonate tidal flat realm, the megatracksite concept and the reptiles that lived in this environment.

\section{Acknowledgements}

I am very grateful to G.F.W. Herngreen, M. Geluk and Th.E. Wong, for their critical reviews of earlier versions of the manuscript. I thank both the quarry director, J. Mentink, who kindly made it possible for me to study the section, and $\mathrm{H}$. Oosterink, who gave me access to invaluable information on the occurrence of invertebrate and vertebrate remains in the Winterswijk section.

\section{References}

Aigner, T. \& Bachmann, G.H., 1991. Sequence stratigraphy of the German Muschelkalk. In: Hagdorn, H. \& Seilacher, A., (eds): Muschelkalk. Schöntaler Symposium 1991: 15-18.

Bachmann, G.H., 1998. The Germanic Triassic: General. Hallesches Jahrbuch für Geowissenschaften B 6: 19-22.

De Boorder, H., Lutgert, J.E. \& Nijman, W., 1985. The Muschelkalk and its lead-zinc mineralization in the eastern Netherlands. Geologie en Mijnbouw 64: 311-326.

Demathieu, G. \& Oosterink, H.W., 1983. Die Wirbeltier-Ichnofauna aus dem Unteren Muschelkalk von Winterswijk (Die Reptilfährten aus der Mitteltrias der Niederlande). Staringia 7: 1-51.

Demathieu, G. \& Oosterink, H.W., 1988. New discoveries of ichnofossils from the Middle Triassic of Winterswijk (the Netherlands). Geologie en Mijnbouw 67 (1): 3-17.

Diedrich, C., 1997. Erste Ausgrabungsergebnisse einer neuen Wirbeltierfährtenfundstelle aus der Oolith-Zone (Bithyn, Unterer Muschelkalk) von Borgholzhausen (Teutoburger Wald, NW-Deutschland). Terra Nostra 97 (7): 42-138.

Diedrich, C., 1998a. Vertebrate tracks of the Oolith-Zone (Bithyn, Lower Muschelkalk) from the middle Teutoburger Wald (NW Germany) and their stratigraphic and palaeogeographical significance. In: Bachmann, G.H. et al. (eds): Triassic Epicontinental Symposium, Halle/Saale, Hallesches Jahrbuch für Geowissenschaften B Geologie Paläontologie und Mineralogie Beiheft (Halle/Saale) 5: 36-37. 
Diedrich, C., 1998b. Stratigraphische Untersuchungen der Ichnofaziestypen einer neuen Wirbeltierfährtenfundstelle aus dem Unteren Muschelkalk des Teutoburger Waldes, NW-Deutschland. Neues Jahrbuch für Geologie und Paläontologie Monatshefte 1998 (10): 626-640.

Diedrich, C., 1998c. Vertebrate track ichnofacies types of the Oolith-Zone (Bithyn, Lower Muschelkalk) in the middle Teutoburger Wald (NW Germany) and their stratigraphical, facieal and paleogeographical significance. Zentralblatt für Geologie und Paläontologie Teil I 9/10 (Vol. 1): 925-940.

Diedrich, C., 2000a. New vertebrate track sites in the Lower Muschelkalk of the Germanic Basin. In: Sachs, S. \& Windolf, R. (eds): First Symposium on European Dinosaurs 14-18 March 2000 (Düsseldorf): 8-9.

Diedrich, C., 2000b. Neue Wirbeltierfährten aus dem Unteren Muschelkalk (Mitteltrias) des Osnabrücker Berglandes und Teutoburger Waldes (NW-Deutschland) und ihre stratigraphische und paläogeographische Bedeutung im Germanischen Becken. Neues Jahrbuch für Geologie und Paläontologie Abhandlungen 217 (3): 369-395.

Diedrich, C., 2001a. Ein bemerkenswerter Reptil-Pubisfund aus der Schaumkalk-Zone (Unterer Muschelkalk) von Niederlistingen, Nordhessen. Philippia (accepted).

Diedrich, C., 2001b. Die Wirbeltierfährtenfundstelle Borgholzhausen (Teutoburger Wald, NW-Deutschland) aus der OolithZone (Bithyn, Unterer Muschelkalk). Paläontologische Zeitschrift (in press).

Diedrich, C., 2001c. Wirbeltierfährten aus dem Unteren Muschelkalk (Mitteltrias) von Thüringen (SE-Deutschland). Neues Jahrbuch für Geologie und Paläontologie Monatshefte (in press).

Diedrich, C. \& Oosterink, H., 2000. Bergings- en Documentatietechniek van Rhynchosauroides peabodyi (Faber) - Sauriersporen op de Grens Boven-Bontzandsteen/Onder Muschelkalk van Winterswijk. Grondboor en Hamer 54 (6): 125-130.

Geluk, M.C. 1998. Palaeogeographic and structural development of the Triassic in the Netherlands - new insights. Zentralblatt für Geologie und Paläontologie Teil I 7/8 (Vol. 1): 727-745.

Geluk, M.C. \& Röhling, H.-G. 1998. High-resolution sequence stratigraphy of the Lower Triassic Buntsandstein: A new tool for basin analysis. Zentralblatt für Geologie und Paläontologie Teil I 7/8 (Vol. 1): 727-745

Götz, A. \& Feist-Burkhardt, S., 1998. Sequenzstratigraphische Interpretation der Kleinzyklen im Unteren Muschelkalk (Mitteltrias, Germanisches Becken). Zentralblatt für Geologie und Paläontologie Teil I 7/9 (Vol. 1): 1205-1219.

Harsveldt, H.M., 1963. Older conceptions and present view regarding the Mesozoic of the Achterhoek, with special mention of the Triassic limestones. Verhandelingen Koninklijk Nederlands Geologisch Mijnbouwkundig Genootschap 21 (2): 109-130.

Harsveldt, H.M., 1973. The Middle Triassic limestone (Muschelkalk) in the Achterhoek (E. Gelderland). Verhandelingen Koninklijk Nederlands Geologisch Mijnbouwkundig Genootschap 29: 43-50.
Knaust, D., 1998a. Trace fossils and ichnofabrics on the Lower Muschelkalk carbonate ramp (Triassic) of Germany: tool for high-resolution sequence stratigraphy. Geologische Rundschau 87: 21-31.

Knaust, D., 1998b. Signatures of tectonically controlled sedimentation in Lower Muschelkalk carbonates (Midle Triassic) of the Germanic Basin. Zentralblatt für Geologie und Paläontologie Teil I 9/10 (Vol. 1): 893-924

Langer, A., 1989. Lithostratigraphische, technologische und geochemische Untersuchungen im Muschelkalk des Osnabrücker Berglandes. Mitteilungen des Geologischen Institutes der Universität Hannover 29: 1-114.

Lotze, F., 1933. Die Verbreitung roter Gesteine im Mittleren Muschelkalk Nordwestdeutschlands. Neues Jahrbuch für Geologie, Mineralogie und Paläontologie, B, Beilagen-Band 69: 388395.

Meyer, C.A., 1993. A sauropod megatracksite from the Late Jurassic of Northern Switzerland. Ichnos 2: 1-10.

NITG-TNO, 1998. Geological Atlas of the deep Subsurface of the Netherlands. Explanation to map sheet X Almelo-Winterswijk (Utrecht): $145 \mathrm{pp}$.

Oosterink, H.W., 1986. Winterswijk, Geologie Deel II. De Triasperiode (geologie, mineralen, en fossielen. Wetenschappelijke Medelingen Koninklijke Nederlandse Natuurhistorische Vereniging 178: 1-120.

Oosterink, H.W., 1988. Voetsporen van Reptielen en Amfibieën uit de Winterswijkse Muschelkalk. Grondboor en Hamer 42 (3/4): 69-78.

Rosenfeld, U. \& Thiele, I., 1992. Der untere Muschelkalk am Nordrand der Rheinischen Masse - Fazies und Mächtigkeiten. Neues Jahrbuch für Geologie und Paläontologie Monatshefte 1992 (8): 487-512.

Schulz, M.G., 1972. Feinstratigraphie und Zyklengliederung des Unteren Muschelkalkes in Nord-Hessen. Mitteilungen des Geologischen und Paläontologischen Institutes der Universität Hamburg 41: 133-170.

Schwarz, H.U., 1975. Sedimentary structures and facies analysis of shallow marine carbonates (Lower Muschelkalk, Middle Triassic, SW-Germany). Contributions to Sedimentology 3: 1-100.

Van Adrichem Boogaert, H.A. \& Kouwe, W.F.P. (compilers), 1994. Stratigraphic nomenclature of the Netherlands; revision and update by RGD and NOGEPA. Section E. Triassic (Lower and Upper Germanic Triassic Groups). Mededelingen Rijks Geologische Dienst 50: 1-28.

Visscher, H. \& Comissaris, A.L.T.M., 1968. Middle Triassic pollen and spores from the Lower Muschelkalk of Winterswijk (The Netherlands). Pollen et Spores 10 (1): 161-176.

Zwenger, W.H., 1992. Die Schichtenfolge: Muschelkalk einschließlich Röt. Sedimentologie-Stratigraphie-Paläontologie. In: Schroeder, J.H. (ed.): Führer zur Geologie von Berlin und Brandenburg. No. 1. Die Struktur Rüdersdorf. Geowissenschaften in Berlin u. Brandenburg e. V. 1992. Selbstverlag Geowissenschaften in Berlin und Brandenburg (Berlin): 31-64. 